\section{Drought Tolerance Responses of Purple Lovegrass and 'Adagio' Maiden Grass}

\author{
Erin Alvarez ${ }^{1}$, S.M. Scheiber, ${ }^{2,4}$, and Richard C. Beeson, Jr. ${ }^{3}$ \\ University of Florida, IFAS, Environmental Horticulture Department, \\ MREC, 2725 Binion Road, Apopka, FL 32703
}

\author{
David R. Sandrock ${ }^{2}$ \\ Oregon State University, Department of Horticulture, $4151 \mathrm{Ag}$ and Life \\ Sciences Building, Corvallis, OR 97331
}

Additional index words. ornamental grasses, Eragrostis spectabilis, Miscanthus sinensis 'Adagio', landscape establishment, landscape irrigation, irrigation application rates, landscape water management, microirrigation, roots, isohydric, anisohydric

\begin{abstract}
Nonnative Miscanthus sinensis Anderss 'Adagio' and native Eragrostis spectabilis (Pursh) Steud. were evaluated for drought tolerance in a rain-excluded landscape setting in sandy soil in response to irrigation application volumes of $0 \mathrm{~L}, 0.25 \mathrm{~L}, 0.5 \mathrm{~L}$, or $0.75 \mathrm{~L}$. As irrigation rates increased, plant mass, canopy size, and shoot-to-root ratios increased for both species, being greatest at the $0.75-\mathrm{L}$ rate. Shoot dry weight, root dry weight, total biomass, and shoot-to-root ratios were greater for $E$. spectabilis than $M$. sinensis. Cumulative water stress integral was also greater for $E$. spectabilis. Greater growth in conjunction with higher cumulative water stress indicates the native E. spectabilis is anisohydric and more drought-tolerant than the isohydric nonnative M. sinensis.
\end{abstract}

Drought and corresponding water restrictions are forcing landscapers and consumers to seek alternative irrigation practices and plants that require minimal irrigation for survival (Knox, 1990). Ornamental grasses are generally regarded as problem-free, low-maintenance plants (Dana, 2002) and recommended for their putative low-water requirements. Relationships between ornamental grasses and water use have been reported (Blicker et al., 2003; Bolger et al., 2005; Greco and Cavagnaro, 2002; Guenni et al., 2002; Mohsenzadeh et al., 2006), yet research quantifying water requirements of ornamental grasses for establishment or maintenance in a residential landscape is limited (Zollinger et al., 2006). Many Florida water management districts have recommended native plants to their consumers (Southwest Florida Water Management District (SFWMD), 2001, 2003) under the premise that Florida native plants use less water than nonnative plants (Haehle, 2004; Hostetler et al., 2003; SFWMD, 2001).

Limited research has been done to substantiate the assumption that native plants use less water than nonnative plants. Kissel et al. (1987) examined water relations of four exotic and three native New Zealand species and found no overall difference existed

\footnotetext{
Received for publication 25 Mar. 2007. Accepted for publication 24 June 2007.

This work supported by the Florida Agricultural Experiment Station.

${ }^{1}$ Graduate Research Assistant.

${ }^{2}$ Assistant Professor.

${ }^{3}$ Associate Professor.

${ }^{4}$ To whom reprint requests should be addressed; e-mailscheiber@ufl.edu.
}

Florida Mid-Florida Research and Education Center in Apopka, FL (lat. $28^{\circ} 41^{\prime} \mathrm{N}$, long. $\left.81^{\circ} 31^{\prime} \mathrm{W}\right)$. Thirty-two plants of each species for a total of 64 plants were planted to original container depth in six rows oriented north-south on $0.6-\mathrm{m}$ centers in $1.5-\mathrm{m}$ wide strips. Planting rows were covered with 7.5 - to $10-\mathrm{cm}$ screened pine bark nuggets to a depth of $7.6 \mathrm{~cm}$ (Sunrise Landscape Supply, Orlando, FL.). Areas between strips were covered with $0.9-\mathrm{m}$ wide strips of polypropylene ground cloth (BWI Companies, Apopka, FL) to inhibit weed growth. Before transplant, soil under the shelter was saturated to a depth of $0.9 \mathrm{~m}$.

The experiment was conducted as a randomized complete block design with two species and four treatments with four replications per treatment $\times$ species combination. There were 32 experimental units (i.e., each species $\times$ treatment combination replicated four times) with each unit containing two plants of the same species for a total of 64 plants. One plant of each species was used for water potential measurements and the other plant of each species was used for growth measurements. Blocks were spatially L-shaped across rows to account for variations in the environment of the rainout shelter. One of four irrigation volumes was applied to each plant within an experimental unit: $0 \mathrm{~L}, 0.25 \mathrm{~L}, 0.50 \mathrm{~L}$, and $0.75 \mathrm{~L}$. Irrigation volumes were applied as one event on alternate days for a $90-\mathrm{d}$ period beginning at transplant through $25-\mathrm{mm}$ polyethylene pipe and $90^{\circ}$ gray spray stakes (Roberts Irrigation Products, San Marcos, CA). Pressure compensators (Bowsmith Super-Drip N.D., Exeter, CA) were placed inline for each emitter to regulate water flow at $1.9 \mathrm{~L} \cdot \mathrm{h}$. Two spray stakes were placed $0.46 \mathrm{~m}$ apart in the northwest and southeast directions to cover a $0.21-\mathrm{m}^{2}$ area around each plant. The Christiansen Coefficient of Uniformity was a minimum of 0.77 before planting (Haman et al., 2005). Irrigation of each experimental unit was controlled as a separate zone using an automated irrigation time clock (model Sterling 12; Superior Controls Co., Valencia, CA). Irrigations began at $0500 \mathrm{HR}$ and were completed by 0600 HR each day. Flow meters (model C700TP, ABS, Ocala, FL) were installed for each zone to record irrigation volumes Monday through Friday.

Weather data. Weather data were obtained from a weather station site at the research site. Reference evapotranspiration $\left(\mathrm{ET}_{0}\right)$ was calculated daily by a CR10X data logger (Campbell Scientific, Logan, UT) using a program supplied in Campbell's Application Note 4D. This program calculates $\mathrm{ET}_{0}$ on an hourly basis using the ASCE Penman-Monteith equation with resistances (Allen et al., 1989). Input for $\mathrm{ET}_{0}$ calculations was measured with a pyranometer (Li-190; LI-COR, Lincoln, NE), anemometer (014; Met-One Instruments, Meford, OR), and temperature/humidity sensor (HMP45CL; Campbell Scientific). Rainfall was recorded with a tipping bucket rain gauge (TE525; Texas Instruments, Dallas, TX). 
Each midnight, the data logger calculated daily $\mathrm{ET}_{0}$.

Growth indices and biomass. At planting, six additional plants of each species were partitioned into roots and shoots, washed to remove substrate, then dried at $70{ }^{\circ} \mathrm{C}$ until a constant mass was obtained for initial shoot and root dry weight values. Plant height, widest canopy width (width 1), and width perpendicular to the widest width (width 2) were recorded to calculate growth indices (growth index $=$ height $\times$ width $1 \times$ width 2 ) at transplant and every $14 \mathrm{~d}$ after planting. On 27 July 2005, the southernmost plant of each species in each experimental unit, the plant not used for water potential readings, was destructively harvested. Shoots were removed to the crown. To obtain root biomass gain, one-fourth segments of the soil volume outside of the original root ball and extending beyond the longest root to the depth of the deepest root in each quadrant were removed from the northeast and southwest sides of each plant. Soil was removed from roots, and shoots and roots were processed as described previously. Dry weights of northeast and southeast segments were summed and multiplied by two to obtain total root biomass gain. Average initial root dry weight in the root ball and total root biomass gain were summed to obtain an estimated total root dry weight for calculation of shootto-root ratios. Shoot biomass gain was calculated as the difference between total shoot dry weight at final harvest and initial shoot dry weight. Total biomass gain was calculated as described for shoot biomass gain. Shoot-toroot ratios were calculated by dividing total shoot dry weight by total root dry weight.

Leaf water potential measurements. Beginning 1 month after transplant (MAT), on 23 May 2005 , leaf water potential $\left(\Psi_{\mathrm{T}}\right)$ was measured monthly. Measurements were made at predawn, midday, and dusk on the nonirrigated day (stressed) and irrigation day (unstressed). Leaf water potential was determined with a pressure chamber (model 3000; Soil Moisture Equipment Corp., Santa Barbara, CA) using compressed nitrogen with pressure increasing at a rate of $25 \mathrm{kPa} \cdot \mathrm{s}$. Measurements were made on individual grass blades $(\approx 10 \mathrm{~cm}$ long) taken from the northernmost plant of each replication. As described by Schulze et al. (1980) and Beeson (1992), cumulative daily water stress integrals $(\mathrm{S} \psi)$ were calculated as the integrated area over the water potential curve and absolute value taken for each replication on each sampling date.

Data analysis. The experiment was conducted as a randomized complete block design with four blocks of single plant replicates. Plants that died during the experiment were included in the analysis as opposed to being represented as missing data. Regression equations were calculated for shoot dry weight gain, root dry weight gain, biomass gain, and shoot-to-root ratios as a function of irrigation volume for each species. For these variables, in which at least one of the regression lines was quadratic, data were analyzed as a two $\times$ four factorial with two species and four irrigation volumes. Comparisons were made between species to determine effects of both species and irrigation volume on dry weight gain. Regression equations were also calculated for growth indices over time at each irrigation volume. Growth indices were analyzed separately by species. Comparisons were only made within a species to determine effects of irrigation volume on growth rate. Where at least one of the regression lines was quadratic, data were additionally analyzed as repeated measures separately by species. Analysis was by split plot with irrigation volume as the main plot and month after transplanting as the subplot. Cumulative water stress integral values, predawn $\Psi_{\mathrm{T}}$, midday $\Psi_{\mathrm{T}}$, and dusk $\Psi_{\mathrm{T}}$, were analyzed as repeated measures using a split plot design with irrigation volume as the main plot, species as a subplot, and stress day as a subsubplot (Snedecor and Cochran, 1980). Each sampling date was analyzed separately. Where significant differences were indicated, mean separation was by Fisher's protected least significant differences
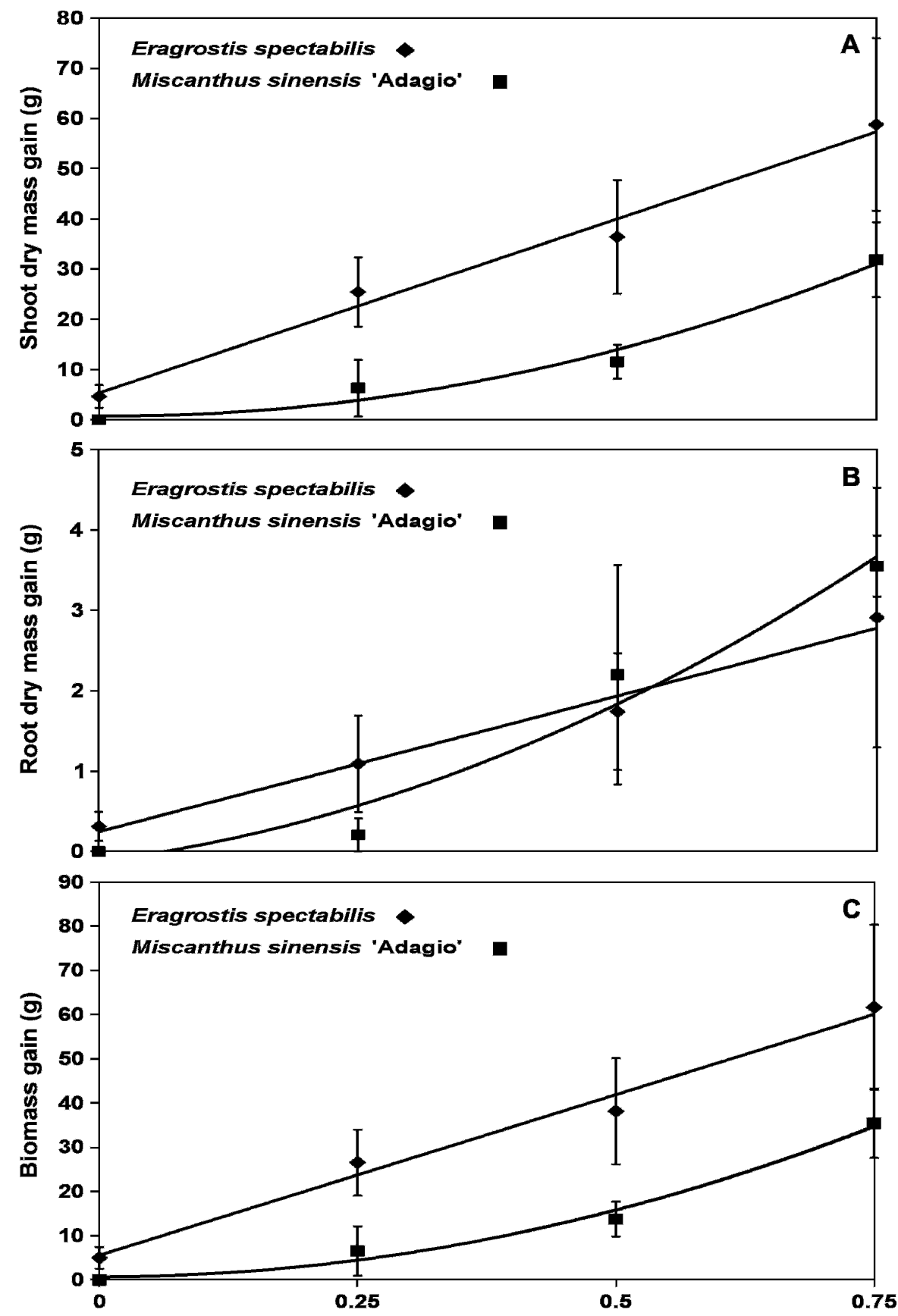

Fig. 1. (A) Shoot biomass gain of Eragrostis spectabilis $(\bullet) \mathrm{y}=69.344 \mathrm{x}+5.326, \mathrm{r}^{2}=0.98$ and Miscanthus sinensis 'Adagio' $(v) \mathrm{y}=56 \mathrm{x}^{2}-1.648 \mathrm{x}+0.808, \mathrm{r}^{2}=0.98$; (B) root biomass gain of $(\bullet) \mathrm{y}=3.3764 \mathrm{x}+$ $0.2471, \mathrm{r}^{2}=0.98$ and $(\mathrm{v}) \mathrm{y}=4.572 \mathrm{x}^{2}+1.6282 \mathrm{x}-0.1215, \mathrm{r}^{2}=0.97$; and $(\mathbf{C})$ total biomass gain of $(\bullet) \mathrm{y}=$ $72.716 \mathrm{x}+5.569, \mathrm{r}^{2}=0.99$ and $(v) \mathrm{y}=60.64 \mathrm{x}^{2}-0.072 \mathrm{x}+0.687, \mathrm{r}^{2}=0.99$. Plants were grown for $90 \mathrm{~d}$ and irrigated every other day with $0 \mathrm{~L}, 0.25 \mathrm{~L}, 0.50 \mathrm{~L}$, or $0.75 \mathrm{~L}$ water. Each point represents the means \pm SE indicated by standard error bars $(n=4)$. 
(F-protected LSD; Snedecor and Cochran, 1980). All analysis was conducted using SAS (version 9.1.3; SAS Institute, Cary, NC).

\section{Results and Discussion}

Mortality. By 3 MAT, $75 \%$ and $25 \%$ of nonirrigated $M$. sinensis and E. spectabilis plants, respectively, were dead. E. spectabilis plants receiving $0.25 \mathrm{~L}$ per event had a $50 \%$ mortality rate.

Biomass. Biomass gain of both $M$. sinensis and E. spectabilis increased with increasing irrigation volumes (Fig. 1A-C). Shoot, root, and total biomass gain of $M$. sinensis increased quadratically, whereas shoot, root, and total biomass gain of $E$. spectabilis increased linearly (Fig. 1A-C). Shoot biomass gain was greatest at $0.75-\mathrm{L}$ treatments and lowest for nonirrigated plants. Shoot biomass gain of E. spectabilis was greater $(P<0.01)$ than $M$. sinensis (Fig. 1A). The $0.75-\mathrm{L}$ treatment increased shoot biomass gain of $E$. spectabilis and $M$. sinensis by $12.6-$ and 32 -fold, respectively, relative to nonirrigated plants.

Root biomass gain increased with increasing irrigation volumes with greater root gain for $E$. spectabilis than $M$. sinensis $(P<0.05)$. At the $0-\mathrm{L}$ and 0.25 -L treatments, root biomass gain of E. spectabilis was higher than $M$. sinensis, although mean values included dead plants (Fig. 1B). Miscanthus sinensis irrigated at $0.75 \mathrm{~L}$ per event had the greatest root biomass gains.

Irrigation rates of $0.75 \mathrm{~L}$ resulted in greater $(P<0.0001)$ total biomass gain than the 0 -L treatment. Other treatment comparisons were similar $(P>0.05)$. Total biomass gain of E. spectabilis was greater $(P<0.01)$ than $M$. sinensis (Fig. 1C). Average total biomass gain of E. spectabilis was greater than M. sinensis by $74 \%, 178 \%$, and $307 \%$ for the $0.75-\mathrm{L}, 0.50-\mathrm{L}$, and $0.25-\mathrm{L}$ treatments, respectively (Fig. 1C).

Observed decreases in biomass with decreased irrigation quantities are well documented. Guenni et al. (2002) recorded a reduction in dry weight for Brachiaria brizantha (A. Rich.) when subjected to moderate drought stress. Dry weight of droughtstressed Gaillardia aristata Pursh was reduced by $50 \%$ and $84 \%$, and dry weight of Leucanthemum $\times$ superbum (Bergmans ex J.Ingram) Soreng \& E.A.Cope was reduced by $47 \%$ and $99 \%$, respectively, when exposed to 2- and 4-week intervals in irrigation (Zollinger et al., 2006). Trichloris crinita (Laq.) Parodi also showed reduced dry weight under drought conditions (Greco and Cavagnaro, 2002) as did drought-stressed Bouteloua eriopoda Torr. and Eragrostis lehmanniana Nees (Fernandez et al., 2002).

Shoot-to-root ratio. Shoot-to-root ratios increased linearly with irrigation volume (data not shown) with larger $(P<0.01)$ ratios for E. spectabilis $(32.19 \pm 28.75)$ than $M$. sinensis $(4.97 \pm 5.80)$. Ratios within a species were similar $(P>0.05)$ among all treatments. Low shoot-to-root ratios of $M$. sinensis at low irrigation volumes were the result of high mortality and exclusion of dead material.
This is consistent with Greco and Cavagnaro (2002), who found no significant difference in shoot-to-root ratio between levels of drought-stressed T. crinita.

Growth indices. Mean growth indices for both species at $0.25-\mathrm{L}, 0.50-\mathrm{L}$, and $0.75-\mathrm{L}$ irrigation treatments generally increased over time. Mean growth indices for the nonirrigated plants decreased over time (Fig. 2A-B). For E. spectabilis, growth indices for $0.25-\mathrm{L}, 0.50-\mathrm{L}$, and 0.75 -L treatments increased by $40 \%, 170 \%$, and $230 \%$, respectively. Growth indices of $M$. sinensis receiving $0.25 \mathrm{~L}, 0.50 \mathrm{~L}$, and $0.75 \mathrm{~L}$ increased by $7 \%, 29 \%$, and $585 \%$, respectively. However, at $0-\mathrm{L}$ and 0.25 -L treat- ment volumes, mean growth indices of both species decreased between 2 MAT and 3 MAT (Fig. 2A-B). Reduced shoot growth and decreased cell elongation are common effects of drought stress, having been observed in multiple experiments (Kalapos et al., 1996; Kramer and Boyer, 1996; Neumann et al., 1988; Sadras and Milroy, 1996; Sakurai and Kuraishi, 1988). In addition, significant leaf necrosis was observed with low irrigation levels. Zollinger et al. (2006) observed leaf death and senescence as a drought avoidance mechanism in herbaceous perennials.

Trends in growth indices were similar $(P$ $<0.05)$ to biomass gains with greater canopy
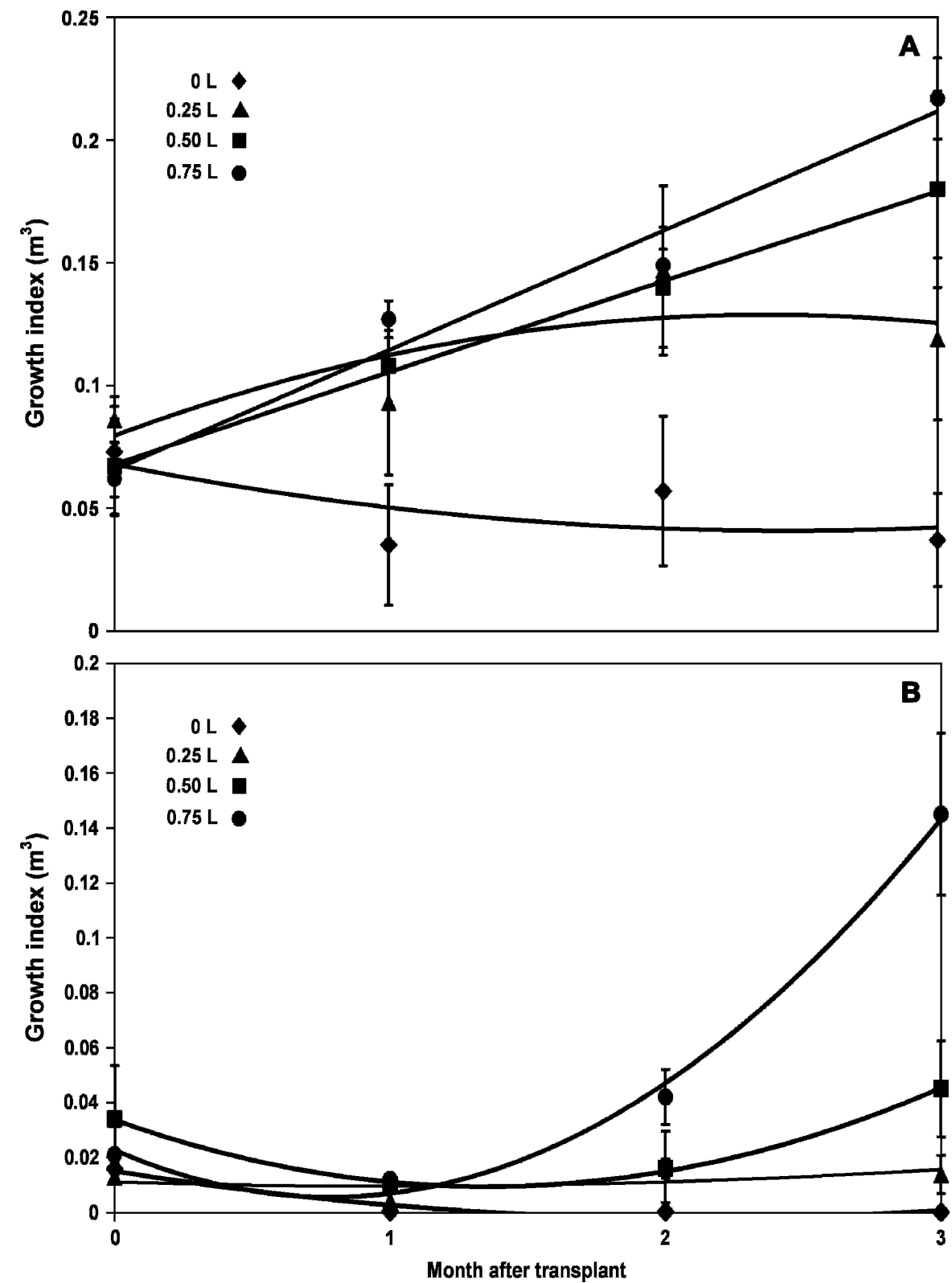

Fig. 2. Mean growth indices for (A) Eragrostis spectabilis irrigated at $0 \mathrm{~L}(\bullet) \mathrm{y}=0.0045 \mathrm{x}^{2}-0.0221 \mathrm{x}+$ $0.0679, \mathrm{r}^{2}=0.46 ; 0.25 \mathrm{~L}(\sigma) \mathrm{y}=-0.0088 \mathrm{x}^{2}+0.0416 \mathrm{x}+0.0795, \mathrm{r}^{2}=0.64 ; 0.5 \mathrm{~L}(\mathrm{v}) \mathrm{y}=0.0371 \mathrm{x}+$ $0.0681, \mathrm{r}^{2}=1.00$; or $0.75 \mathrm{~L}(\lambda) \mathrm{y}=0.0487 \mathrm{x}+0.0657, \mathrm{r}^{2}=0.97$ and $(\mathbf{B})$ Miscanthus sinensis 'Adagio' irrigated at $(\diamond) \mathrm{y}=0.0038 \mathrm{x}^{2}-0.0162 \mathrm{x}+0.015, \mathrm{r}^{2}=0.93 ;(\sigma) \mathrm{y}=0.0015 \mathrm{x}^{2}-0.0031 \mathrm{x}+0.0111$, $r^{2}=0.24 ;(v) y=0.0133 x^{2}-0.0359 x+0.0336, r^{2}=1.00$, or $0.75 L(\lambda) y=0.028 x^{2}-0.0438 x+0.0227$, $\mathrm{r}^{2}=1.00$ per event over a 3 -month period during summer in central Florida. Each point represents the means \pm SE indicated by standard error bars $(n=4)$. 
size at higher application rates (Figs. $1 \mathrm{~A}-\mathrm{C}$ and 2A-B). For both species, canopy size was greatest $(P<0.05)$ at $0.75-\mathrm{L}$ and smallest within the $0-\mathrm{L}$ treatment. At $3 \mathrm{MAT}$, the $0.75-\mathrm{L}$ treatment increased the mean growth index of E. spectabilis by 3.75 times relative to the $0-\mathrm{L}$ treatment and $M$. sinensis by 7.5 times relative to the 0.25 -L treatment.

Water potentials. Irrigation treatment effects only occurred twice during the experiment. An irrigation effect was observed at 2 MAT for the midday $\Psi_{\mathrm{T}}$, in which $0-\mathrm{L}$ $(-1.7 \mathrm{MPa})$ and $0.25-\mathrm{L}(-1.6 \mathrm{MPa})$ treatments were similar $(P>0.05)$ yet more negative $(P<0.05)$ than $0.50-\mathrm{L}(-1.2 \mathrm{MPa})$ and $0.75-\mathrm{L}(-1.2 \mathrm{MPa})$ treatments. At $3 \mathrm{MAT}, \mathrm{S} \psi$ was greater $(P<0.05)$ for nonirrigated plants $(24.0 \mathrm{MPa} \cdot \mathrm{h})$ compared with grasses receiving $0.25,0.50$, and $0.75 \mathrm{~L}(19.3,16.7$, and 16.1 $\mathrm{MPa}$, respectively). Cumulative water stress was comparable $(P<0.05)$ between $0.75-\mathrm{L}$ and $0.50-\mathrm{L}$ treatments. For both sampling periods, $\Psi_{\mathrm{T}}$ became more negative as the irrigation amount decreased, indicating higher stress levels occurred as less water was applied to plants.

Species effects, however, were seen at 2 and 3 MAT for predawn, midday, and dusk readings; each time, $\Psi_{\mathrm{T}}$ was more negative for $E$. spectabilis than for $M$. sinensis except for 2 MAT predawn (Table 1). Cumulative water stress was also greater $(P<0.05)$ for $E$. spectabilis at 2 MAT than M. sinensis (Table 1). Higher shoot-to-root ratios of E. spectabilis account for increased water stress resulting from the inability of the root system to compensate for transpirational water losses (Gilman et al., 1998; Montague et al., 2000).

A stress day $\times$ species interaction was observed in S $\psi$ at 1 and 3 MAT (Fig. 3). At $1 \mathrm{MAT}, \mathrm{S} \psi$ was highest for E. spectabilis on the nonirrigated day (stress day) and lowest for E. spectabilis on the irrigation day (unstressed day). Cumulative water stress results were intermediate for $M$. sinensis with comparable values between stressed and unstressed days. Results were similar for $M$. sinensis at 3 MAT except regardless of stress day; $\mathrm{S} \psi$ was higher for E. spectabilis compared with $M$. sinensis $(P<0.05)$. For $E$. spectabilis, $\mathrm{S} \psi$ was higher on the unstressed day $(24.9 \mathrm{MPa} \cdot \mathrm{h})$ than on the stressed day (19.7 MPa.h) $(P<0.01)$ (Fig. 3). Weather effects likely influenced these results. Regardless of whether E. spectabilis plants were irrigated, S $\psi$ (Fig. 3) was always highest on days with the highest the $\mathrm{ET}_{0}$, which also occurred on days with the greatest incident solar radiation (Fig. 2). This suggests $E$. spectabilis transpiration and therefore $g_{\mathrm{S}}$ were coupled to microclimate and less sensitive to water stress. These responses are consistent with anisohydric behavior in which stomata remain open independent of water potentials (Tardieu and Simonneau, 1998). Conversely, there was little change in $\mathrm{S} \psi$ of M. sinensis whether or not plants were irrigated the day of measurement. This suggests these plants were decoupled from the microclimate and their transpiration was limited by water stress-inducing stomatal

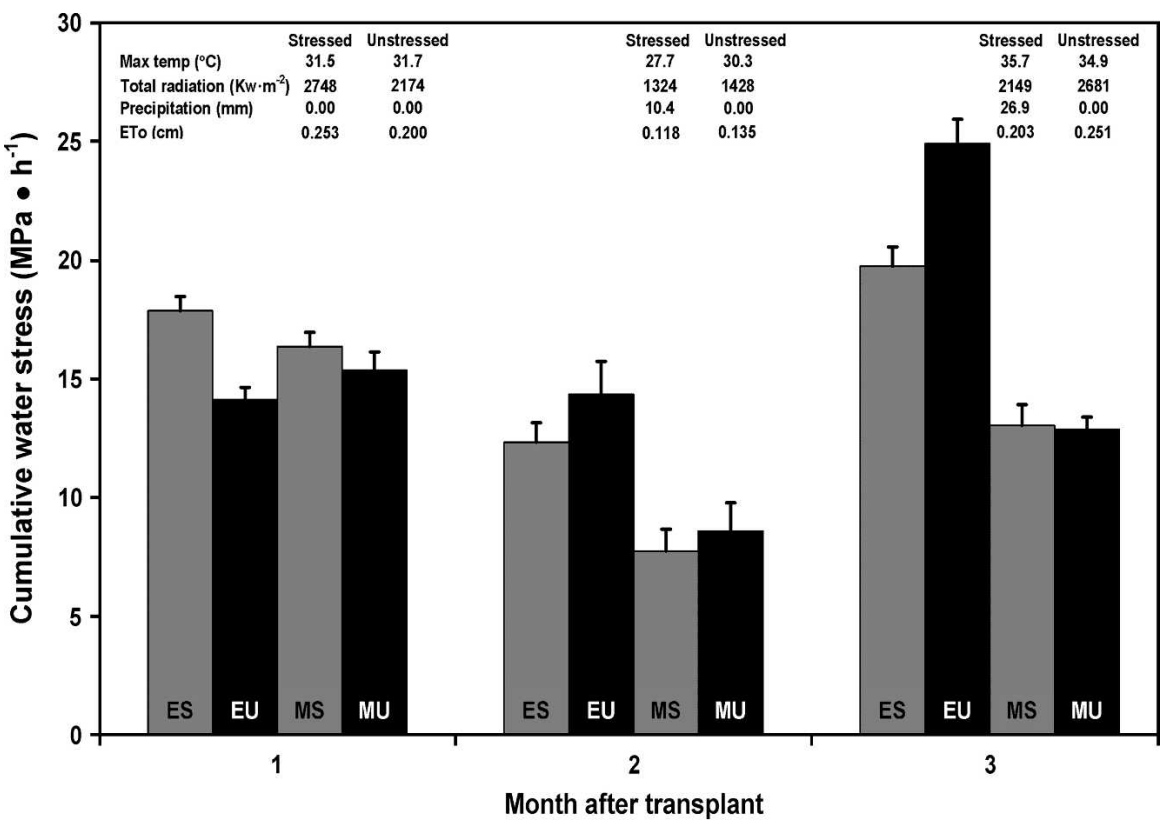

Fig. 3. Cumulative daily water stress integrals $(\mathrm{S} \psi)$ calculated monthly on the day before irrigation (stressed) and irrigation day (unstressed) for Eragrostis spectabilis and Miscanthus sinensis 'Adagio' irrigated with four irrigation rates $(0,0.25,0.50$, or $0.75 \mathrm{~L})$ over a 3-month period during summer in central Florida. ES = Eragrostis spectabilis - nonirrigated day (stressed); EU = Eragrostis spectabilis-irrigation day (unstressed); MS = Miscanthus sinensis-nonirrigated day (stressed); MU = Miscanthus sinensis - irrigation day (unstressed). Each point represents the means \pm SE indicated by standard error bars $(n=4)$.

Table 1. Predawn water potential, midday water potential, dusk water potential, and cumulative daily water stress integrals $(\mathrm{S} \psi)$ calculated monthly for ornamental grass species irrigated with $0,0.25,0.50$, or $0.75 \mathrm{~L}$ per irrigation event over a 3-month period during summer in central Florida.

\begin{tabular}{lllccc}
\hline MAT $^{\mathrm{z}}$ & \multicolumn{1}{c}{ Species } & $\begin{array}{c}\text { Predawn } \Psi_{\mathrm{T}} \\
(\mathrm{MPa})\end{array}$ & $\begin{array}{c}\text { Midday } \Psi_{\mathrm{T}} \\
(\mathrm{MPa})\end{array}$ & $\begin{array}{c}\text { Dusk } \Psi_{\mathrm{T}} \\
(\mathrm{MPa})\end{array}$ & $\begin{array}{c}\text { Cumulative } \\
\text { water stress, } \mathrm{S}_{\Psi} \\
(\mathrm{MPa} \cdot \mathrm{h})\end{array}$ \\
\hline 2 & $\begin{array}{l}\text { E. spectabilis } \\
\text { M. sinensis }\end{array}$ & $-0.131 \mathrm{a}^{\mathrm{yx}}$ & $-1.67 \mathrm{a}$ & $-0.35 \mathrm{a}$ & $13.34 \mathrm{a}$ \\
& $P$ value & $>0.105 \mathrm{a}$ & $-1.02 \mathrm{~b}$ & $-0.19 \mathrm{~b}$ & $8.17 \mathrm{~b}$ \\
& $>0.05$ & $<0.0151$ & $<0.0305$ & $<0.0149$ \\
3 & E. spectabilis & $-0.216 \mathrm{a}$ & $-2.61 \mathrm{a}$ & $-1.13 \mathrm{a}^{\mathrm{w}}$ & $22.33 \mathrm{a}^{\mathrm{v}}$ \\
& M. sinensis & $-0.129 \mathrm{~b}$ & $-1.69 \mathrm{~b}$ & $-0.28 \mathrm{~b}$ & $12.92 \mathrm{~b}$ \\
& $P$ value & $<0.0357$ & $<0.0005$ & $<0.05$ & $<0.05$ \\
\hline
\end{tabular}

${ }^{\mathrm{z}}$ Months after transplant.

${ }^{y}$ Means calculated from four single plant replicates.

${ }^{\times}$Mean separations within columns and species $(P<0.05)$.

wValues represent pooled dusk water potential means; however, species effect cannot be clearly identified as a result of a significant species $\times$ stress day interaction $(P<0.05)$.

${ }^{v}$ Values represent pooled S $\psi$ species means; however, species effect cannot be clearly identified as a result of a significant species $\times$ stress day interaction $(P<0.05)$.

closure indicating these are isohydric (Tardieu and Simonneau, 1998). This interpretation of the water relations data is consistent with the higher biomass gains of $E$. spectabilis despite generally lower $\Psi_{\mathrm{T}}$ measurements recorded the last 2 months after transplanting. Similar results were seen for sunflower and barley, anisohydric species, and maize and poplar, isohydric species (Tardieu and Simonneau, 1998).

\section{Conclusions}

Across treatments, both grasses had similar trends with increased biomass gain and canopy size with increasing irrigation rates. The greatest portion of biomass gain for both species was shoot biomass, with little species effect seen for root biomass gain.
Miscanthus sinensis has a larger mature size than E. spectabilis (Darke, 1999). However, overall growth of E. spectabilis was normally greater $(P<0.05)$ than $M$. sinensis across all treatments. For $M$. sinensis, low biomass gain and low water stress integrals indicate stomata were closed most of the time under low irrigation volumes. Isohydratic plants strive to maintain constant water potentials in response to drought conditions at the expense of biomass gain (Tardieu and Simonneau, 1998). In contrast, greater biomass gain and higher water stress integrals of E. spectabilis indicate stomata remained open for photosynthesis and subsequent biomass gain. Anisohydric plants seek biomass gain by tolerating low water potentials under drought conditions (Tardieu and Simonneau, 1998). 
Although E. spectabilis is a native plant, its higher tolerance to moderate water stress than $M$. sinensis does not necessarily imply that native grasses outperform nonnatives in drought situations. Water use and drought tolerance vary greatly from species to species, even varying by genotype within species. Careful evaluation of individual grass species and sites should always be performed when selecting plants for low water-use landscapes.

\section{Literature Cited}

Allen, R.G., M.E. Jensen, J.L. Wright, and R.D. Burman. 1989. Operational estimates of reference evapotranspiration. Agron. J. 81:650-662.

Anella, L. 2000. Debunking native myths. Amer. Nurseryman. 192:39-43.

Beeson, R.C. 1992. Restricting overhead irrigation to dawn limits growth in container-grown woody ornamentals. HortScience 27:996-999.

Blicker, P.S., B.E. Olson, and J.M. Wraith. 2003. Water use and water-use efficiency of the invasive Centaurea maculosa and three native grasses. Plant Soil 254:371-381.

Bolger, T., A. Rivelli, and D. Garden. 2005. Drought resistance of native and introduced perennial grasses of south-eastern Australia. Austral. J. Agr. Res. 56:1261-1267.

Chapman, D. and R. Auge. 1994. Physiological mechanisms of drought resistance in four native ornamental perennials. J. Amer. Soc. Hort. Sci. 199:299-306.

Dana, M.N. 2002. Ornamental grasses and sedges as new crops. Trends in new crops and new uses. p. 473-476. ASHS Press, Alexandria, VA.

Darke, R. 1999. The color encyclopedia of ornamental grasses. Timber Press, Portland, OR.

Fernandez, R., M. Wang, and J. Reynolds. 2002. Do morphological changes mediate plant responses to water stress? A steady-state experiment with two $\mathrm{C}_{4}$ grasses. New Phytol. 155:79-88.
Gilman, E.F., R.J. Black, and B. Dehgan. 1998. Irrigation volume and frequency and tree size affect establishment rate. J. Arboricult. 24:1-9.

Glenn, E., R. Tanner, S. Mendez, T. Kehret, D. Moore, J. Garcia, and C. Valdes. 1998. Growth rates, salt tolerance and water use characteristics of native and invasive riparian plants from the delta of the Colorado River, Mexico. J. Arid Environ. 40:281-294.

Greco, S.A. and J.B. Cavagnaro. 2002. Effects of drought in biomass production and allocation in three varieties of Trichloris crinita P. (Poaceae) a forage grass from the arid Monte region of Argentina. Plant Ecol. 164:125-135.

Guenni, O., D. Marin, and Z. Baruch. 2002. Responses to drought of five Brachiaria species. I. Biomass production, leaf growth, root distribution, water use and forage quality. Plant Soil 243:229-241.

Haehle, R. 2004. Native Florida plants: Low maintenance landscaping and gardening. Taylor Trade Publishing, Lanham, MD.

Haman, D.Z., A.G. Smajstrla, and D.J. Pitts. 2005. Efficiencies of irrigation systems used in Florida nurseries. Univ. Fla. Institute of Food and Agricultural Sciences Coop. Ext. Serv. Bul. 312.

Hostetler, M., G. Klowden, S. Miller, and K. Youngentob. 2003. Landscaping backyards for wildlife: Top ten tips for success. UF/IFAS EDIS Publication \#UW175.

Kalapos, T., R. van Den Boogaard, and H. Lambers. 1996. Effect of soil drying on growth, biomass allocation and leaf gas exchange of two annual grass species. Plant Soil 185:137149.

Kissel, R.M., J.B. Wilson, P. Bannister, and A.F. Mark. 1987. Water relations of some native and exotic shrubs of New Zealand. New Phytol. 107:29-37.

Knox, G. 1990. Landscape design for water conservation. UF/IFAS EDIS Publication \#ENH72.

Kramer, P.J. and J.F. Boyer. 1996. Water relations of plants and soils. 2nd ed. Academic Press, San Francisco.
Mohsenzadeh, S., M.A. Malboobi, K. Razavi, and S. Farrahi-Aschtiani. 2006. Physiological and molecular responses of Aeluropus lagopoides (Poaceae) to water deficit. Environ. Exp. Bot. 56:314-322.

Montague, T., R. Kjelgren, and L. Rupp. 2000. Gas exchange and growth of two transplanted, fieldgrown tree species in an arid climate. HortScience 35:763-768.

Neumann, P., E. Van Volkenburgh, and R. Cleland. 1988. Salinity stress inhibits bean leaf expansion by reducing turgor, not wall extensibility. Plant Physiol. 88:233-237.

Sadras, V.O. and S.P. Milroy. 1996. Soil water thresholds for the responses of leaf expansion and gas exchange: A review. Field Crops Res. 47:253-266.

Sakurai, N. and S. Kuraishi. 1988. Water potential and mechanical properties of the cell wall of hypocotyls of dark-grown squash (Curcubita maxima Duch.) under water-stress conditions. Plant Cell Physiol. 29:1337-1343.

Schulze, E.D., A.E. Hall, O.L. Lange, M. Evenari, L. Kappen, and U. Buschbom. 1980. Longterm effects of drought on wild and cultivated plants in the Negev desert. I. Maximal rates of net photosynthesis. Oecologia 45:11-18.

Snedecor, G.W. and W.G. Cochran. 1980. Statistical methods. 7th ed. Iowa State Univ. Press, Ames, IA.

Southwest Florida Water Management District (SWFWMD). 2001. Waterwise south Florida landscapes.

Southwest Florida Water Management District (SWFWMD). 2003. Year-round water conservation measures. Chapter 40D-22.

Tardieu, F. and T. Simonneau. 1998. Variability among species of stomatal control under fluctuating soil water status and evaporative demand: Modelling isohydric and anisohydric behaviors. J. Expt. Bot. 49:419-432.

Zollinger, N., R. Kjelgren, T. Cerny-Koenig, K. Kopp, and R. Koenig. 2006. Drought responses of six ornamental herbaceous perennials. Scientia Hort. 109:267-274 